\title{
Neoliberalism, Applied Linguistics and the PNLD ${ }^{1}$
}

\author{
Vanderlei J. Zacchi \\ Universidade Federal de Sergipe \\ Sergipe, AL, BR
}

\begin{abstract}
Based on the book Neoliberalism and Applied Linguistics (Block, Gray \& Holborow, 2012a), this paper aims at discussing the relationship between these two concepts. After a general discussion on the subject, the paper will deal with the use of celebrities in English language textbooks as an element of identification and as a means to advance neoliberal values. A second aspect refers to the promotion of social and cultural diversity and pluralism in a way that may be also attending to the market's interests. These aspects will finally be analysed in the series Links (Santos \& Marques, 2009a, 2009b, 2009c), of the National Textbook Program (PNLD) for primary education. Whereas the textbooks use celebrities and present other neoliberal tendencies, they also propose activities that seek to promote citizenship and inclusion, probably in order to fulfil the Ministry of Education's demands through PNLD. This ambiguity may be related to the fact that the PNLD is a state-run program for public education that relies on the commercial editorial market to produce and sell the textbooks.
\end{abstract}

Keywords: Textbook; ELT; Neoliberalism; Multiculturalism

\section{Introduction}

In the recently released book Neoliberalism and Applied Linguistics, Block, Gray and Holborow (2012a) seek to explore the complex relationship between these two areas, more specifically the way in which the latter has come to be influenced by the former. Neoliberalism has come under attack from various areas of interest, but much more so from the left wing sphere. Block, Gray and Holborow tend to follow such a trend. All in all, the idea is that neoliberal discourses and practices have effected the privatisation of education services, setting the priority of education to be "an engine for economic growth" (2012b, p. 7). Although such concern is worth taking into consideration, the authors seem to generalise this tendency and ignore other small scale power struggles involving the fields of education and, more specifically, applied linguistics and language teaching.
According to Harvey (2005, p. 2) neoliberalism "proposes that human well-being can best be advanced by liberating individual entrepreneurial freedoms and skills within an institutional framework characterized by strong private property rights, free markets, and free trade". Kubota $(2014$, p. 12) describes it in similar terms, adding that the privatization of public services has a key role in the promotion of a free market economy. The result, according to her, is the creation of a flexible workforce and an increase in the "individual and institutional accountability for economic success". She also contends that global capitalism has caused neoliberalism to support economic activities across national borders. Dardot and Laval (2013, p. 202), in turn, dismiss the strict connection between neoliberalism and the "religion of the market" by stating that neoliberal policies were in fact implemented in the name of the effectiveness of "systems of government action", under the disguise of "modernity".

\footnotetext{
"Vanderlei J. Zacchi is adjunct professor at Universidade Federal de Sergipe and an adjunct associate of the Centre for Globalization and Cultural Studies at the University of Manitoba in Canada. He holds a PhD in Linguistic and Literary Studies in English from Universidade de São Paulo and currently coordinates ANPOLL's working group on Transculturalism, Language and Education. E-mail: vanderleiz@yahoo.com
} 
In the field of education, Block, Gray and Holborow (2012b, p. 6) sustain that the impact of neoliberalism resulted in a shift from pedagogical to market values, which involves another, more profound, shift in educational philosophy: "the abandonment of the social and cooperative ethic in favour of individualist and competitive business models", generating, among other things, greater social inequality. One of the issues put forward by the authors is the use of celebrity discourses in English language teaching (henceforth ELT) textbooks as a way to connect English with wealth, individualism and professional success (p. 11), in a world where success is regarded as "the supreme value" (Dardot \& Laval, 2013, p. 317). This is the issue on which this paper will more specifically focus, bearing in mind that individualism, according to Gray (2012, p. 94 ), is the point of connection between celebrity and neoliberalism. It would be useful to show, however, the way in which certain textbooks follow such a trend while at the same time professing a discourse aimed at citizenship building and collective agency.

That seems to be the case of the collection Links, adopted, since 2011, in primary public schools in Brazil. For Kumaravadivelu (2008, p. 186), it is "imperative" to pay great attention to the designing of teaching materials and textbooks, especially because they are ubiquitous in the language classroom and seem to have "a magical hold" over teachers and students. Another important reason is that these materials are never a neutral medium, since they usually carry hidden cultural values, despite the fact that more recent textbooks, probably due to globalization, have included a variety of activities on issues such as racism, human rights and the environment. Nevertheless, he adds, even textbooks with "good intentions" may carry subtle messages. ${ }^{2}$

So the Links collection was created to attend to certain criteria posed by the Ministry of Education (MEC), through the Programa Nacional do Livro Didático (PNLD - National Textbook Program), as a condition for its adoption in schools. A number of these criteria, following multicultural dispositions, seek to give visibility to minority groups as a way to promote them and consequently redress social inequalities. But, on the other hand, the books present other discourses such as the ones related to celebrity and individualism - that do not fit into that category. The result is a type of patchwork that seems to attend to the interests of both the government and the private market. Although the federal government is the main, if not the sole, commercial client for these books, some of the values and ideas circulated by them may be in accordance with neoliberal discourses that emphasize individual goals, in contrast with some of the PNLD criteria, as mentioned above. One probable reason for this contrast is the fact that the PNLD is a state-run program for public schools that nevertheless involves a commercial dimension, since the books themselves are produced by private companies that obviously seek financial profits.

Such contrastive elements will be analysed in further detail below, with examples from books from the Links series (Santos \& Marques, 2009a, 2009b, 2009c). Before going into that analysis, I will briefly discuss the connections between neoliberalism and applied linguistics, and the use of celebrity discourses in ELT textbooks. In both cases, the discussion will take Block, Gray and Holborow's book (2012a) as a starting point.

\section{Neoliberalism and Applied Linguistics}

So much of the recent discussion about the effects of neoliberalism has undertaken an apocalyptic connotation. There is a tendency to believe that, under neoliberalism, life itself is doomed to failure. Peter McLaren (1999, p. 64), for instance, states that neoliberalism and globalization seek to "democratize suffering, obliterate hope and assassinate justice" whereas, for Henry Giroux (2005), "it is easier to imagine the end of the world than the end of neoliberal capitalism."

Another aspect presented by authors is that several items, if not all, have been commodified, becoming nothing but a product to be sold. For Giroux (2005) and Heller (2010), language itself has become a commodity. David Harvey (2005), in turn, goes much further and denounces "The commodification of everything", in a way that precludes a market that works as an ethic for all human action (p. 165). In this vein, Holborow 
(2012) is critical of the many theorists who, mostly influenced by Michel Foucault's discourse theory, usually place social inequalities in terms of discourses and narratives rather than as the result of economic and political practices. Thus, when conceptualized via Foucauldian discourses, the analysis of neoliberalism becomes overly individualized and preoccupied with issues of representation.

Fairclough (2006, p. 3) defines discourse as "a way of representing some part or aspect of the world". The neoliberal economic discourse, he exemplifies, claims that markets are "self-regulating", so that the role of states and governments, far from that of interfering with the markets, would be to "facilitate" the works of the markets. On the one hand, Fairclough seeks to distinguish discourse from actual processes of neoliberalism (although his main focus is globalization). On the other hand, though, he stresses that the former actually contribute to creating and shaping the latter. So the neoliberal economic discourse is not only a representation, but it has also been highly influential in shaping global economic processes and relations in a particular way.

Holborow (2012, p. 25) believes that language, in fact, is "something rather different to sticks and stones", so that neoliberalism is not just the result of power affairs set relationally, but actually the cause of several types of social, political and economic inequalities throughout the world. Kubota $(2014$, p. 2) names a few of them: ethnic conflicts, civil wars, racism, xenophobia, growing economic gaps both nationally and internationally, not to mention standard language ideology and the dominance of English. For her, applied linguistics alone will not tackle these "real problems", as she calls them (p. 9), but "some are within the purview of our discipline" (p. 2). The challenge would be to promote significant socio-political and economic changes for people who are using, learning and teaching language. In a similar vein, Holborow (2012) does not believe that language and discourse shape the real and the social but are secondary factors. So she tends not to take into account that "we never encounter reality in its bare factuality. We always experience the world through its representation. [...] reality is encoded for us as a particular phenomenon" (Hoechsmann \& Poyntz, 2012, p. 78). Consequently, she is inclined to ignore the idea that both reality and society are not fixed, but social constructs that change from place to place, from time to time and from one group of people to another.

Moreover, as pointed out by Chun (2013, p. 64), neoliberal policies have generated contestations at various local levels and, in the English language classroom, they have been debated to include learners' roles, ranging from passively complacent students to democratic activists articulating their own needs. It is undeniable, however, that neoliberalism has its negative social and economic impact. And that it has been imposed by hegemonic groups to meet their own agendas. For Giroux (2005, p. 210), neoliberalism, with its "free market fundamentalism", is one of the most dangerous ideologies of the twenty-first century. Ultimately it has come to occupy all available social space (Holborow, 2012, p. 16). Scholte (2005, p. 307) describes the supporters of neoliberal policies as "secular fundamentalists" who sustain an uncritical rationalism based on "the gospel of science, the dogma of efficiency, and the cult of progress". According to McLaren, placing obstacles to mergers, profit and accumulation, for them, is the same as going against freedom and democracy, so "the paranoid ego" (1999, p. 69) needs to be canonized, while the external world is represented as demonic. Capital, for neoliberalism supporters, is synonymous with freedom and vital for democracy; therefore, to criticize capitalism is to attack freedom and democracy itself.

Although to a certain extent I share these negative views on neoliberalism, I see in many of these critiques, especially those put forward by Block, Gray and Holborow, a great deal of determinism, as if citizens in society at large were completely unable to stand themselves critically in relation to the values and practices circulating within neoliberal capitalism. This is particularly true of their analysis of ELT textbooks, as I will discuss in greater depth below. As stated by Dovey and Kennedy (2006, p. 76), dominance implies power and, inevitably, produces resistance. Therefore, those identities and narratives that do not fit the hegemonic mould become excluded. The point is that they are 
never fixed or completely determined, but contested and negotiated since "power is a dynamic process through which other, alternate and subversive identities are being constantly generated. The field commanded by the dominant is never 'fixed, or final', but exists in constant contestation and redevelopment" (p. 64).

As for the relationship between neoliberalism and applied linguistics, Block, Gray and Holborow (2012b) state that, in the field of applied linguistics, any reference to neoliberalism has been largely avoided. In fact, there has been a tendency to separate issues related to language teaching from those of the social sciences and education in general. ${ }^{3}$ That is more perceptible, according to them, within the field of ELT. As an example, they mention the fact that, in the United Kingdom, the attendees at the International Association of Teachers of English as a Foreign Language (IATEFL) conference are not the same as those at the British Association for Applied Linguistics (BAAL) conference. ${ }^{4}$

Two authors who have discussed, even if tangentially, the relationship between languages and the mechanisms of the market are Norman Fairclough (2006) and Alastair Pennycook (2007). In fact, both are rather concerned with the mechanics of globalization, and that implies, to a certain degree, the inclusion of the free market and neoliberalism in the discussion as well. A common aspect to both authors is the refusal to subscribe to the cultural (and linguistic) imperialism thesis, i.e. the idea that the world is dominated by powerful media corporations, especially from the U.S., which disseminate Western cultural values (the English language included) and threaten local cultures. Neither of them sees globalization as a homogenizing process.

Fairclough (2006, p. 40) brings together a series of discourses that represent globalization from a reductive neoliberal economic point of view. That is what he calls "globalism": discourses that link globalization to the integration of markets and define it as inevitable, irreversible and beneficial to everyone. On the other hand, he also identifies a type of globalization from below (p. 121) that makes use of new discourses, practices and identities for the development of local and particular strategies. Fairclough states that discourse can be used, among other things, to project a particular point of view about globalization and thus legitimate actions and strategies that are consistent with that point of view. In that case, critical discourse analysis becomes a fundamental tool for him.

Pennycook (2007, p. 1), in turn, observes that much of the North American rap music disseminated around the world (and appropriated by musicians from various countries) is characterized by a popular African American variable of the English language, which is very different from any formal and official version of it. Pennycook (p. 95) also criticizes what he calls a "bourgeois-leftist politics" for analyzing popular music, which tends to praise "bands that convey an anticapitalist, anti-globalist, anti-racist, environmentally friendly pro-feminist message" as examples of the "progressive" aspects of popular culture while avoiding those that take up "unacceptable" cultural and political positions. Pennycook believes that hip-hop lyrics need also to be understood according to the variety of language used in them, which are linked to change, resistance and opposition as much as "lyrics that overtly challenge the status quo" (p. 138).

Holborow (2012), however, dismisses the possible contributions that both Fairclough and Pennycook (among others) may add to the discussion. Thus they are both seen as paying tribute to Foucault for his theorising of discourse (p. 24), Fairclough in the field of critical theory, and Pennycook within applied linguistics. Therefore, "Fairclough's ever expanding view of discourse overflows to drown the social and economic system. In this frame of reference, discourse analysis assumes the same status as social events" (p. 23). As for Pennycook, "His interesting study shows convincingly that world English never simply smothers those obliged to speak it. But he exaggerates the transformative role that performative linguistics can play, and seems to equate adopting critical stances with social change" (p. 26). As we can see, Block, Gray and Holborow's analysis is reductive and deterministic in itself, since they downplay the sheer possibility of discourse coming to cause social change.

But the authors' position about English in the world is rather contradictory. On the one hand, it is seen as the language of neoliberalism and globalization 
(Holborow, 2012, p. 16-17). This point of view seems to have become a common sense, especially among English teachers. In Brazil, many of them believe that English is the natural language of globalization (Zacchi, 2006). On the other hand, according to Gray (2012, p. 111), English is also one of the languages of global resistance, a situation that indicates the necessity to produce and disseminate materials that "embody values other than those expressed by the ELT industry".

In a way, the institution of the PNLD, as far as foreign languages are concerned, has aimed at promoting such values, which may be expressed through issues involving social inequality, minority groups, citizenship building and collective agency. The program instituted by the federal government also works as a guide for commercial publishers that intend to produce textbooks for public schools. Not following the guidelines set by the program may mean having textbooks refused. Such textbooks should, then, be tailored for a specific purpose: public education. To a certain extent, the ones that I will analyze below embody the values just mentioned. At the same time, however, some of their texts and activities seem to be influenced by neoliberal trends, more specifically celebrity discourse and aspirational content, as proposed by Gray (2012). In the next section, I will examine both aspects in a series of textbooks produced for the PNLD.

\section{English, celebrity and the PNLD}

According to Gray (2012), together with the spread of neoliberalism across the world, from the late 1970s until the present there has been a strong rise in representations of celebrity in ELT textbooks, especially those produced in the UK. Consequently, the proliferation of celebrities in contemporary culture has led to the so-called "aestheticisation of everyday life", in other words, "the way in which signs, images and visual messages feature so prominently in all aspects of daily activity" (p. 87). Behind this aestheticisation process lie an urge for self-promotion and the need to attract attention. According to Driessens (2013, p. 641), celebrity has become a defining characteristic of "our mediatized societies", being present in various types of media and affecting several social fields. Consequently, it has become "a valued resource to be used in power struggles". For him, celebrities have also been commodified and contribute to the propagation of neoliberal discourses.

Gray (2012) suggests that the proliferation of celebrities in ELT textbooks is congruent with the values of neoliberalism and is connected with what ELT publishers call "aspirational content"; i.e. such content, focused on celebrity lifestyles, cosmopolitanism and travel is motivating for language learners. Therefore,

the UK ELT industry itself can usefully be seen as a type of culture industry in which core products such as standardised textbooks aimed at the global market perform the ideological task of reinforcing the link between English and professional success, one form of which is the spectacular success achieved by some celebrities, in which their power to consume lavishly and the lifestyles they can afford feature prominently. (Gray, 2012, p. 94)

As a result, he believes that developing-world teachers subscribe, uncontested, to such a "dominant ideology" (p. 107). However, one aspect to be highlighted here is that the promotion of neoliberal ideas in these books should not be taken at face value. As Hoechsmann and Poyntz (2012, p. 32) mention about children that are exposed to branding and the language of market in the media, "this does not mean young people are naïve about the way brands target them as consumers". The same could be said about textbook users. The fact that these materials present neoliberal values does not necessarily imply that teachers and students take them fully and uncritically.

Celebrity discourse and aspirational content can also be found in ELT textbooks produced in Brazil. In 2011, English language textbooks were introduced, for the first time, in the PNLD. The program presupposes the distribution of Brazilian foreign language textbooks to all public schools in the country. ${ }^{5}$ The schools choose them from an assortment of collections previously selected and bought by the federal government from private publishers. The selection of the collections involves a complex evaluation process 
with strict guidelines. This first version included a guide containing 92 different aspects to be followed, divided into fourteen sections (Brasil, 2010). In 2012, another set of collections was introduced, this time for secondary education. For primary education, in 2011, only two series were approved: Links and Keep in mind. Each series is divided into four different levels and is comprised of students' books, teacher's books and audio CDs. Contrary to what happens with textbooks for other disciplines, PNLD's foreign language textbooks are non-reusable, i.e. students can use them freely because they will not be reused by other students in the following year. Nevertheless, there are accounts of teachers and schools around the country that do not allow them to take their books home, which is quite limiting for the students.

The analysis below was conducted on the basis of activities and texts taken from the Links series (Santos \& Marques, 2009a, 2009b, 2009c), more specifically volumes 1, 2 and 4 . The selection of the excerpts was done for the purpose of a qualitative rather than quantitative analysis. Therefore, the selection was based on excerpts that are representative of both the aspects under analysis here, respectively: a focus on celebrities, aspirational content and individualism as a reflection of neoliberal values, as well as an attempt to meet the requirements of the Ministry of Education regarding certain social and cultural issues, as will be shown below.

The analysis shows that the books belonging to the series are no exception to the tendency to invest in representations of celebrity and aspirational content, as put forward by Gray (2012). After an analysis of a few books published in the United Kingdom, he mentions that this tendency started in the late 1970s. According to him, that was when the ELT industry intensified its global expansion and neoliberalism spread across much of the world. Streamline Connections, for example, published in 1979, presents a number of celebrities in its pages: James Hunt, Paul McCartney and Elvis Presley, among others. In more recent publications, like the New Headway Advanced, published in 2003, Gray (2012, p. 104) also noticed that they "encourage students to consider ways of becoming celebrities".
As for the Links series, the books are fraught with representations of celebrities and aspirational content, which, according to Gray (2012), is indicative of neoliberal values. Some examples are: Oprah Winfrey, Nelson Mandela, Nicole Kidman, Sean Connery, Nelly Furtado, Russell Crowe, Kaká, Kate Winslet and Lázaro Ramos (Santos \& Marques, 2009a, p. 73). Such a list is illustrative of how diversified celebrity has become (Driessens, 2013, p. 647). Apart from actors and actresses, there is also a football player (Kaká) and a statesman (Nelson Mandela). In another activity, there is a text called exactly "Celebrities" (Santos \& Marques, 2009a, p. 67), and it brings a picture of the British actress Keira Knightley along with some personal data about her. The personal data include information such as "favorite book" and "favorite movie", and it is not clear whether they are real or not, since there is no indication of source for the information provided.

Regarding aspirational content, one activity in particular is very paradigmatic. It is a reading and writing activity that shows a picture of Brazilian F1 racer Felipe Massa, together with the picture of a boy and his statement:

Felipe Massa is my role model. He's cool! He's a great F1 driver. He's fast but he's not furious. His favorite actor is Robert de Niro and his role models are Ayrton Senna and Michael Schumacher. Felipe Massa is an inspiration to me! (Santos \& Marques, 2009a, p. 74)

The writing portion of the activity prompts the students to write about their role models. So this activity is a clear example of the use of aspirational content in textbooks. It even sets up a lineage of F1 racers, beginning with Ayrton Senna and Michael Schumacher and going down to the boy character in the textbook. And the writing activity motivates the student to actually write about a celebrity of his/ her choice. The idea of the role model, in this case, corroborates with Driessens' statement that celebrity status "is supposed to function as a general token of success" (2013, p. 642). This idea is also stressed by the fact that the role model is usually gender motivated. Whereas the activity about Felipe Massa is mainly 
directed to boys, the activity about Keira Knightley (Santos \& Marques, 2009a, p. 67) seems to have girls as potential targets, since it shows a picture with two girls reading a magazine about the actress and talking about her. Such specification, expressed in the choice of students' gender, intensifies the idea that these celebrities function as role models for them.

The activity also privileges another aspect of neoliberalism, the freedom of objective and rational choice: "you can be anything you want as long as you 'fit in"' (Andreotti \& Menezes de Souza, 2008, p. 26). Behind such an assertion is the idea that everyone has equal opportunities, but only the fittest will win. This places an enormous emphasis on individualism and highlights neoliberalism's impact on the actual conduct of individuals by stimulating them to be self-sufficient and not rely on collective solidarity. And

to calculate and maximize their interests by pursuing more individual logics in a context of more radical competition with one another. In other words, neo-liberal strategy consisted, and still consists, in constantly and systematically guiding the conduct of individuals as if they were always and everywhere engaged in relations of transaction and competition in a market. (Dardot \& Laval, 2013, p. 210)

As a result, individuals have been led to face their performance as a product of self-management, thus becoming "entrepreneurs", whose ethic is dedicated to monitoring the self. Dardot and Laval call it an ethic of "self-help" (p. 293). Moreover, they argue, techniques of self-management aim at a transformation of all areas of individual life. Therefore, the enterprise of subjects produced by neoliberal rationality involves conducting themselves as entities in a competition, who must maximize results and expose themselves to risks. So, no longer regarded as "workers", they are seen as enterprises that sell a service in the market. Sportspeople are illustrative in this respect. Since the world of sport is becoming "an unabashed laboratory of business" (p. 312), sportspeople "are perfect embodiments of the self-entrepreneur, who have no hesitation in selling themselves to the highest bidder without any considerations of loyalty and fidelity". So the ethics of enterprise, according to Dardot and Laval (p. 294), turns work into "the priviledged vehicle of selfrealization: it is by succeeding professionally that one makes a 'success' of one's life'.

\section{Multiculturalism and critique}

On the other end of the spectrum, the collection tries to meet some requirements from MEC that follow a different agenda, not so much concerned with individual success or celebrity idolatry. Thus activities that try to come to terms with issues such as diversity, citizenship, minority rights, respect and tolerance were also added. Nevertheless, some of these activities rely on traditional mechanical exercises that are not exactly appropriate for fostering reflection, like drilling exercises that serve mainly to instigate repetition (see, for example, Santos \& Marques, 2009b, p. 21-22). Open ended questions could be an alternative possibility here. But one way to deconstruct representations of neoliberal identities in materials, according to Chun (2013), is to adopt critical literacy pedagogy, since it can help students to engage with materials that portray representations of the world which might be incongruent with their own lived experiences. Critical literacy pedagogy implies contextualized and heterogeneous use of language (Brasil, 2006). Therefore, it runs counter decontextualized approaches to language teaching - like the one based on mechanical, non-reflective activities - that tend to produce homogeneous and universal linguistic skills.

An example of an attempt to raise students' awareness through a mechanical activity such as gap filling can be seen in the exercise below:

"According to the Brazilian Statute of the Child and Adolescent, an adolescent is someone from ___ to ___ years of age." (Santos \& Marques, 2009c, p. 66)

Any other topic could fit into such an exercise, since there is neither a proposition of discussion about it, nor some sort of activity that might lead to a reflection 
about the topic and about the place hold by the students themselves in society.

The principles and criteria that guided the production and evaluation of the textbooks were established in a document prepared by the Ministry of Education (Brasil, 2008). Some of them involve the following (p. 35):

- the books should "encourage pedagogical action towards respect and the valorization of diversity, and towards the concepts of sustainability and active citizenship, supporting democratic pedagogical practices and the exercise of respect and tolerance"; ${ }^{6}$

- the books should positively promote minority rights, such as those of women, indigenous communities, African-Brazilians and children.

- for the evaluation of foreign language textbooks in particular:

- the books must "present cultural references, avoiding all kinds of indoctrination, discrimination, stereotypes or prejudice in texts and images" (p. $57) ;$

- the collections should contribute to citizenship building: guarantee opportunities for the recognition of and respect for local and global diversity and for "the interpretation of differences among languages and cultures, as well as of the social and political consequences of the hierarchization of these differences, which cause several inequalities" (p. 61). ${ }^{8}$

These criteria were transposed to the guide used for the evaluation of the textbooks. As mentioned, this guide contains 92 questions, ranging from the quality of the paper used in the production of the textbooks to structural aspects of the language and to citizenship issues. So the criteria above were translated into questions, such as:
- 42 . Does the proposal presuppose the diversity of teaching and learning contexts (urban and rural) in which the book will be used, presupposing the diversity of the target audience?9 (BRASIL, 2010, p. 16)

- $\quad$ 86. Is global and local diversity recognized and treated with respect? ${ }^{10}$ (p. 18)

- 91. Is the image of women, Afro-descendants and indigenous groups positively promoted, taking into account their participation in different professions, jobs and spaces of power? ${ }^{11}$ (p. 19)

It is worth stressing, at this stage, that issues such as diversity, plurality and citizenship do not necessarily counter neoliberalism. According to Kubota, plurilingualism, for instance, is considered to be essential for working in global capitalism, and it was promoted

to support learning to communicate across borders (via various linguistic repertoires) and respect for linguistic diversity, language rights, freedom of expression, and democratic citizenship. This aligns with the neoliberal emphases on the development of individual competencies in service of economic growth: lifelong learning of communication skills to be developed as individual responsibility; flexible, pragmatic, and truncated language repertoires as essential competence for transcultural workers; and cultural competence that facilitates individual and national economic development. (Kubota, 2014, p. 13)

Moreover, several issues claimed by civil rights movements and by intellectuals and scholars in favor of multiculturalism have already been appropriated by the market. It is not unusual to see in textbooks diversity and multiculturalism represented by multi-ethnic groups. The second volume of the Links series, for example, presents us with a group of eight characters: four girls and four boys (Santos \& Marques, 2009b, p. 9). If gender representation is balanced, a different trend is followed when it comes to ethnic choices, since most of the characters are white people, apart from an Afro-Brazilian boy and a Japanese-Brazilian girl. This 
way of representing ethnic minority groups does not necessarily tackle inequality. In fact, it tends to mask conflicts by pretending to treat everybody as if they were all equals in society.

Multiculturalism itself, as Cannen (2007, p. 93) observes, is informed by different and sometimes contradictory variants. Thus, a liberal version of the term celebrates cultural diversity while overlooking social, political and economic inequalities. Critical multiculturalism, in turn, not only takes into account such inequalities but also challenges the historical making of prejudice, discrimination and cultural hierarchization. This variant, not in tune with neoliberal values, is probably the one adopted by the PNLD. For Kumaravadivelu (2008, p. 106-107), multiculturalism in general has not changed unequal social status and power structure. Critical multiculturalists, in turn, defend educational reforms to foster sociopolitical access, based on the premises that classroom reality is "socially constructed, politically motivated, and historically determined". Therefore, he adds, "any serious multicultural education must attempt to transform the relationship between the classroom and the sociopolitical forces operating in the wider community".

As for citizenship, neoliberalism has also claimed its share of ownership over it. However, textbook activities may foreground citizenship without falling into the trap of neoliberalism if they lead students to a reflection upon and an understanding of the place that they hold in society: are they included in or excluded from the social and cultural process under analysis (Brasil, 2006, p. 93)? Such a reflection might ultimately lead students to decide whether or not they want to keep that place in society or change it; whether or not such change should be extended to society as a whole, and so on.

So, many of MEC's requirements were observed in the Links series. As mentioned above, one of the questions posed as criteria for whether or not approving the textbooks was: "Is local and global diversity recognized and treated with respect?" (Brasil, 2010 , p. 18). One attempt to follow that criterion is a writing activity that shows some pieces of information about Angola - such as the name of the capital city and the population of the country - and prompts the student to write about a country of his/her choice (Santos \& Marques, 2009a, p. 83). It seems that this activity was included in the book only to meet the requirements, in this case randomly presenting a Portuguese-speaking African country as a way to promote global diversity. Nevertheless, the approach does not necessarily imply that the students will reflect on any issue related to Africa or Angola. As a result, the showcasing of this kind of diversity only reinforces the idea that the social groups presented in the book might be seen as mere curiosity. A reflective approach to that would be left then to the teacher. In any case, just by showing these diverse social groups, and this might minimally be one of MEC's goals, the books avoid reinforcing ways of life regarding hegemonic groups and countries. The risk is to bypass inequality by way of promoting diversity as a natural, conflict-free phenomenon in Brazil and in the world.

Another activity, from the section "Let's stop and think" (p. 95), shows a picture of a man stating that "Brazil is much more than that" and looking at another picture with a stereotypical portrayal of the country, since it lists coffee, snakes, soccer and Carnival as the main Brazilian features. The question posed is: "What is Brazil for you?", but it is not very clear what kind of activity is being proposed, whether oral or written production, individually or collectively. Then in another unit, for the same section ("Let's stop and think"), there is the following heading: "Ethics and consumerism: fashion of all ages", and the question: "What are future generations going to think about today's fashion?" (Santos \& Marques, 2009c, p. 27). It shows a picture of several pieces of clothing from different periods in history. Thus, it is possible to notice the authors' vague attempt to combine a type of market oriented content with the demands from MEC, disguising the activity as one that may induce students to reflect critically about a certain subject: in this case, fashion. ${ }^{12}$

\section{Conclusion}

The approach presented by the textbooks analyzed above turns out to be ambiguous when neoliberal values, based on individualism in particular, and a 
discourse around diversity and citizenship are put together. This is probably a way to come to terms with the demands from MEC while keeping a certain standard that has been dominant in the ELT textbook industry. Aspirational content, i.e. the one focused on celebrity lifestyles, cosmopolitanism and travel (Gray, 2012, p. 94), can be seen as part of that standard, which directly or indirectly precludes a connection between English and personal, professional success. The criteria proposed by the federal government seem to pose a break from this traditional way of creating textbooks for ELT, although more substantial results might still take a while to come about.

On the other hand, ELT textbook publishers have a commercial and financial interest in this process. Even so, they can still have their profit by following the approach demanded by the government. Once the books have been approved, the market for them is secured. In this case, adopting a neoliberal discourse that seeks to highlight individual success does not guarantee a commercial success for the textbooks. But following MEC's criteria is more likely to do so. This is probably a moment of transition from one model to another, where the changes proposed by the governing body have not yet been fully assimilated, especially if we take into account the fact that the evaluation and selection of books takes place every three years and that the Links collection was selected in the first round of such process.

Block, Gray and Holborow's point of view about neoliberalism is very much worth taking into account. But it seems that the connection between neoliberalism and applied linguistics comes with a deterministic overtone. And their analysis, especially the one related to textbooks, seems to be too much focused on its economic underpinnings, as opposed to the cultural, social and pedagogical dimensions of teaching. Neoliberalism is certainly a pervasive phenomenon in the present world. The production of textbooks may very well reflect such pervasiveness, be it in the form of celebrity discourse or by promoting diversity to serve the market. The ambiguities in the PNLD's criteria and in the Links series may be the result of a government-funded program that operates within a neoliberal capitalist market. So the ambiguities shown in the textbooks are part of a larger set of ambiguities that involves the program itself and society. Whereas the complete eradication of such ambiguities is little probable, MEC's initiative with PNLD seems to be a good step forward in the production of materials that "embody values other than those expressed by the ELT industry" (Gray, 2012, p. 111).

\section{Notes}

1. Previous versions of this paper were presented at the Brazil-Canada Knowledge Exchange meeting in Toronto, on 16 October 2012, and at the Round Table Conferences on EFL Learning and Teaching in Vitória da Conquista, on 5 August 2013. The research for this paper was made possible, in part, through support provided by the SSHRC partnership development grant \#890-2010- 0050, 'Brazil/ Canada knowledge exchange: developing transnational literacies', and its various contributing partners. I thank Dr. Brian Morgan of York University in Canada for his comments on an earlier version of this paper.

2. He exemplifies it with an activity from a book called Topics in language and culture for teachers, published in 2004 in the U.S. He mentions one exercise about different cultures, which was totally built on stereotypes and dichotomies, such as individualism/ community, tradition/innovation, religious/secular. The exercise asks students to separate these aspects into two columns: one for US culture and one for "other cultures". Kumaravadivelu concludes that it is not "unreasonable" to assume that students will link words such as individualism, innovation and secularism with US culture and community, tradition and religion with "other cultures" (KUMARAVADIVELU, 2008, p. 186187).

3. We might say that in Brazil the tendency to separate these fields is not so strong (see, for example, Brasil, 2006; Maciel, 2011; Monte Mór, 2011; Rajagopalan, 2003; Zacchi, 2006).

4. Again, we might say that that is not the case in Brazil if we compare the attendees at the ABRAPUI (Associação Brasileira de Professores Universitários de Inglês) conference with those at CBLA (Congresso Brasileiro de Linguística Aplicada), as far as English language teaching is concerned.

5. The foreign languages program is comprised of English and Spanish only, since these are the main foreign languages taught in public schools.

6. "incentivar a ação pedagógica voltada para o respeito e valorização da diversidade, aos conceitos de sustentabilidade e da cidadania ativa, apoiando práticas pedagógicas democráticas e o exercício do respeito e 
da tolerância”. (The translation of this passage and of the following ones is mine.)

7. "apresentar referèncias culturais, evitando todo tipo de doutrinação, discriminação, estereótipos ou preconceitos em textos e imagens".

8. "interpretação das diferenças entre línguas e culturas, bem como das consequências sociais e políticas da hierarquização dessas diferenças, que causam desigualdades diversas".

9. "A proposta prevê a diversidade de contextos de ensino e aprendizagem (urbanos e rurais) nos quais a obra será usada, prevendo a diversidade do público-alvo ao qual ela se destina?"

10. "A diversidade global e local é reconhecida e tratada com respeito?"

11. "A imagem da mulher, do afro-descendente e das etnias indígenas é promovida positivamente, considerando sua participação em diferentes profissões, trabalhos e espaços de poder?".

12. Fashion is a recurrent topic in the series. There is one whole unit dedicated to it (Santos \& Marques, 2009b, p. 58-67). From a discussion about whether or not to wear school uniform, the section "Let's stop and think" closes the unit with the implied question: "What kind of clothes do you like to wear?".

\section{References}

Andreotti, V., \& Menezes De Souza, L.M. (2008). Learning to read the world through other eyes. Derby: Global Education.

Block, D., Gray, J. \& Holborow, M. (2012a). Neoliberalism and Applied Linguistics. London / New York: Routledge.

Block, D., Gray, J. \& Holborow, M. (2012b). Introduction. In D. Block, J. Gray, \& M. Holborow. (2012a). Neoliberalism and Applied Linguistics (pp. 1-13). London / New York: Routledge.

Brasil. (2006). Secretaria de Educação Básica. Orientações Curriculares para o Ensino Médio: linguagens, códigos e suas tecnologias (v. 1, pp. 85-124). Brasília: MEC/ SEB.

Brasil. (2008). Edital de convocação para inscrição no processo de avaliação e seleção de coleções didáticas para o Programa Nacional do Livro Didático - PNLD 2011. Brasília: Ministério da Educação, Secretaria de Educação Básica. ftp://ftp.fnde.gov.br/web/livro_ didatico/edital_pnld_2011.pdf (acessed 10 January 2014).

Brasil. (2010). Guia de livros didáticos: PNLD 2011: Língua Estrangeira Moderna. Brasília: Ministério da Educação, Secretaria de Educação Básica.
Canen, A. (2007). O multiculturalismo e seus dilemas: implicações na educação. Comunicação e Política, 25 (2), 91-107.

Chun, C.W. (2013). The "neoliberal citizen": resemiotizing globalized identities in EAP materials. In: J. Gray (Ed.). Critical perspectives on language teaching materials (pp. 64-87). Hampshire: Palgrave Publishers.

Dardot, P. \& Laval, C. (2013). The new way of the world: on neoliberal society. Trans. Gregory Elliott. London / New York: Verso.

Dovey, J.; Kennedy, H.W. (2006). Game cultures: computer games as new media. Maidenhead: Open University Press.

Driessens, O. (2013). The celebritization of society and culture: Understanding the structural dynamics of celebrity culture. International Journal of Cultural Studies, 16 (6), 641-657.

Fairclough, N. (2006). Language and globalization. London: Routledge.

Giroux, H. (2005). Challenging neoliberalism's new world order. In H. Giroux. Border crossings. (pp. 209-220). 2. ed. New York/London: Routledge.

Gray, J. (2012). Neoliberalism, celebrity and 'aspirational content" in English language teaching textbooks for the global market. In D. Block, J. Gray, \& M. Holborow. (2012a). Neoliberalism and Applied Linguistics (pp. 86113). London / New York: Routledge..

Harvey, D. (2005). A brief history of neoliberalism. Oxford: Oxford University Press.

Heller, M. (2010). The commodification of language. Annual Review of Anthropology, 39, 101-114.

Hoechsmann, M.; Poyntz, S. (2012). Media literacies: a critical introduction. Chichester: Wiley-Blackwell.

Holborow, M. (2012). What is neoliberalism? Discourse, ideology and the real world. In D. Block, J. Gray, \& M. Holborow. (2012a). Neoliberalism and Applied Linguistics (pp.14-32). London / New York: Routledge.

Kubota, R. (2014). The Multi/Plural Turn, Postcolonial Theory, and Neoliberal Multiculturalism: Complicities and Implications for Applied Linguistics. Applied Linguistics, 1-22. http://applij.oxfordjournals.org.

Kumaravadivelu, B. (2008). Cultural globalization and language education. New Haven / London: Yale University Press.

McLaren, P. (1999). Utopias provisórias: as pedagogias críticas num cenário pós-colonial. Trans. Helena B. Mascarenhas de Souza. Petrópolis: Vozes.

Maciel, R.F. (2011). From innovation to language policy: towards a locus of research in Applied Linguistics. 
In: R.F. Maciel \& V.A. Araújo (Ed.). Formação de professores de línguas: ampliando perspectivas (pp. 217254). Jundiaí: Paco Editorial.

Monte Mór, W. (2011). Critical literacies in the Brazilian university and in the elementary/secondary schools: the dialectics between the global and the local. In: R.F. Maciel \& V.A. Araújo (Ed.). Formação de professores de linguas: ampliando perspectivas (pp. 307-318). Jundiaí: Paco Editorial.

Pennycook, A. (2007). Global Englishes and transcultural flows. London: Routledge.

Rajagopalan, K. (2003). Por uma lingüística crítica: linguagem, identidade e a questão ética. São Paulo: Parábola Editorial.

Santos, D.; Marques, A. (2009a). Links: English for Teens. São Paulo: Ática. v. 1.

(2009b). Links: English for Teens. São Paulo: Ática. v. 2.

(2009c). Links: English for Teens. São Paulo: Ática. v. 4.

Scholte, J.A. (2005). Globalization: a critical introduction. 2. ed. Basingstoke: Palgrave MacMillan.

Zacchi, V.J. (2006). Discursos da globalização nas vozes de professores e professoras de língua inglesa. Trabalhos em Linguística Aplicada, 45 (1), 9-27.

Recebido em: 21/08/2015

Aceito em: 08/10/2015 